Check for updates

Cite this: RSC Adv., 2019, 9, 29070

Received 21st July 2019

Accepted 9th September 2019

DOI: 10.1039/c9ra05630k

rsc.li/rsc-advances

\title{
Development of improved dual-diazonium reagents for faster crosslinking of tobacco mosaic virus to form hydrogels $\uparrow$
}

\author{
Dejun Ma, (D) $t^{b}$ Zhuoyue Chen, $\star^{a}$ Long Yi (D) *a and Zhen $\mathrm{Xi}^{* \mathrm{bc}}$
}

New bench-stable reagents with two diazonium sites were designed and synthesized for protein crosslinking. Because of the faster diazonium-tyrosine coupling reaction, hydrogels from the crosslinking of tobacco mosaic virus and the reagent DDA-3 could be prepared within $1 \mathrm{~min}$ at room temperature. Furthermore, hydrogels with the introduction of disulfide bonds via DDA-4 could be chemically degraded by dithiothreitol. Our results provided a facile approach for the direct construction of virusbased hydrogels.

\section{Introduction}

Hydrogels are widely used as biomedical materials in manufacturing cell culture matrices, ${ }^{1}$ tissue engineering scaffolds ${ }^{2}$ drug delivery systems ${ }^{3}$ and wound dressing $s^{4}$ due to their unique properties, such as water retention capacity, softness, controllability and biocompatibility. ${ }^{5}$ One of the main approaches for preparing hydrogels is the chemical crosslinking of hydrophilic polymers (natural or synthetic) to provide desirable mechanical and chemical properties. ${ }^{6}$ As natural hydrophilic polymers, plant viruses like tobacco mosaic virus (TMV, $300 \mathrm{~nm} \times 18 \mathrm{~nm}$ ) exhibit a nanoscale size and abundant amino acid residues on their surface of capsid proteins, which facilitate facile chemical reactions to produce nanomaterials with multiple functions. ${ }^{7}$ Furthermore, plant viruses could be largely produced in gram-scale quantities and are also considered much safer to mammals than human-associated viruses like adenovirus and lentivirus in drug delivery and tissue engineering. ${ }^{8}$ Hence, using of plant viruses as building blocks to assemble virus-based hydrogels is attractive in biomedical applications. ${ }^{9}$

Recently, there are mainly two approaches to utilizing plant viruses to construct hydrogels. Firstly, mixture of TMV with hydrogels alters their properties. As reported, the incorporation

${ }^{a}$ State Key Laboratory of Organic-Inorganic Composites, Beijing University of Chemical Technology, Beijing 100029, China.E-mail: yilong@mail.buct.edu.cn

${ }^{b}$ State Key Laboratory of Elemento-Organic Chemistry, Department of Chemical Biology, National Pesticide Engineering Research Center (Tianjin), Nankai University, Tianjin, 300071, China. E-mail: zhenxi@nankai.edu.cn; Tel: +86 22 23504782

${ }^{c}$ Collaborative Innovation Center of Chemical Science and Engineering, Nankai University, Tianjin, 300071, China

$\dagger$ Electronic supplementary information (ESI) available. See DOI: 10.1039/c9ra05630k

\$ The authors contribute equally to the work. of TMV into the porous alginate hydrogels greatly reduced the immunogenicity in mice, and the covalent incorporation of tobacco mosaic virus into poly (ethylene glycol) diacrylate hydrogels increased the stiffness. ${ }^{\mathbf{1 0}}$ Secondly, the hydrogels are directly made through chemically crosslinking TMV virus matrix, which was rarely explored. In our previous work, a TMVbased hydrogel was prepared by crosslinking TMV with a dualdiazonium reagent DDA-1 (Scheme 1). ${ }^{\mathbf{1 1}}$ However, the virusbased hydrogels should be made within at least $30 \mathrm{~min}$ at $37^{\circ} \mathrm{C}$ due to the relatively low diazonium-tyrosine (Tyr) coupling reaction ${ }^{\mathbf{1 2}}$ between DDA-1 and Tyr residues.

In this work, we designed and synthesized three new dualdiazonium reagents (DDA-2, DDA-3, DDA-4) to investigate the effects of substituents ( $\mathrm{CO}, \mathrm{PO}, \mathrm{SO}_{2}$ ) on the crosslinking efficiency and gelation conditions. To our delight, DDA-3/DDA-4 could quickly crosslink TMV matrix as hydrogels within $1 \mathrm{~min}$ at room temperature. Moreover, the DDA-4-based hydrogel could

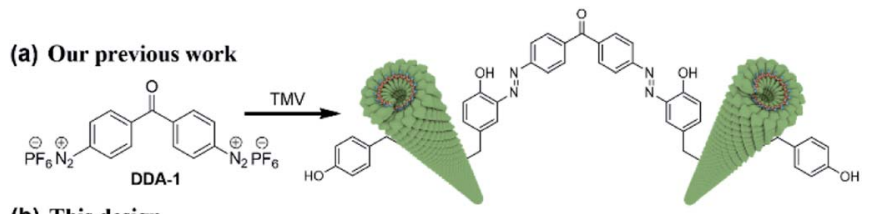

(b) This design
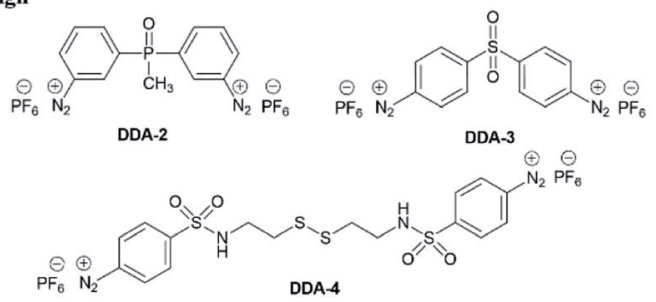

Scheme 1 (a) Schematic illustration for crosslinking via TMV and DDA1 in our previous work; (b) the chemical structure of new dual-diazonium reagents (DDA-2, DDA-3 and DDA-4). 
be efficiently degraded with reducing chemicals like dithiothreitol (DTT), which enhanced the biocompatibility and biodegradability of such hydrogel.

\section{Results and discussion}

As shown in Scheme 2, DDA-2 was obtained by nitration, reduction, diazotization and hexafluorophosphoric acid precipitation from the inexpensive methyl biphenyl phosphine oxide. The final product DDA-2 (white solid) was obtained after mixing 2 with the concentrated $\mathrm{HCl}, \mathrm{NaNO}_{2}$ and $\mathrm{HPF}_{6}$ in onepot. DDA-3 (light yellow solid) could be prepared from 4,4'diaminodiphenyl sulfone in one-pot synthesis. For DDA-4, cystamine was firstly reacted with 4-acetamidobenzenesulfonyl chloride to provide 3 , which was then hydrolysed with the concentrated $\mathrm{HCl}$ to give 4 . After treatment of the concentrated $\mathrm{HCl}, \mathrm{NaNO}_{2}$ and $\mathrm{HPF}_{6}$ in one-pot, a yellow solid DDA-4 was obtained with good yield.

These dual-diazonium reagents (DDA-2, DDA-3 and DDA-4) were well characterized by ${ }^{1} \mathrm{H}$ NMR, ${ }^{13} \mathrm{C}$ NMR, ${ }^{31} \mathrm{P}$ NMR (see the ESI $\dagger$ ). Compared with the chemical shift of 2 in ${ }^{1} \mathrm{H}$ NMR (less than $8 \mathrm{ppm})$, the high chemical shift $(9.19,8.86,8.63$ and 8.17 ppm) of DDA-2 implied the existence of a positively charged diazonium moiety. Affected by phosphorus, the methyl group in DDA-2 was split into two peaks in ${ }^{1} \mathrm{H}$ NMR and ${ }^{13} \mathrm{C}$ NMR. The ${ }^{31} \mathrm{P}$ NMR implied the existence of two kinds of phosphorus, in which the seven peaks were the result of the coupling of six fluorine nucleuses in hexafluorophosphate. Since the dualdiazonium salt was not successfully characterized by mass spectrum, we tried to react DDA-2 with 4,4'-methylenediphenol to get $\mathbf{5}$. The structure of $\mathbf{5}$ was clearly confirmed by ${ }^{1} \mathrm{H}$ NMR, ${ }^{13} \mathrm{C}$ NMR spectra and high-resolution mass spectra (HRMS),

(a)
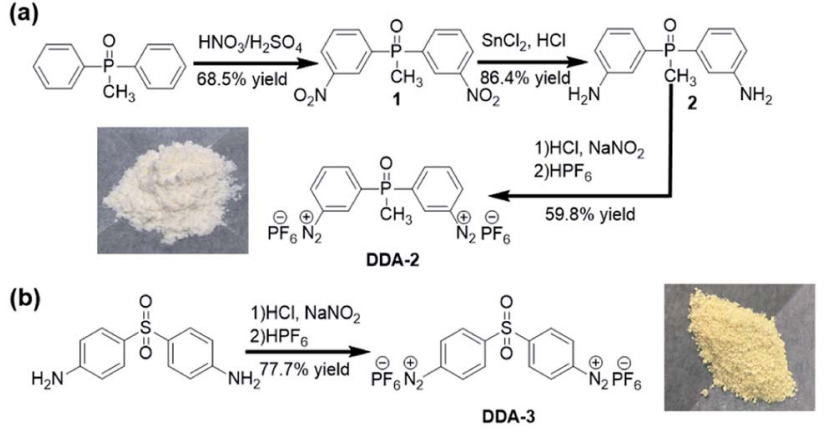

(c)

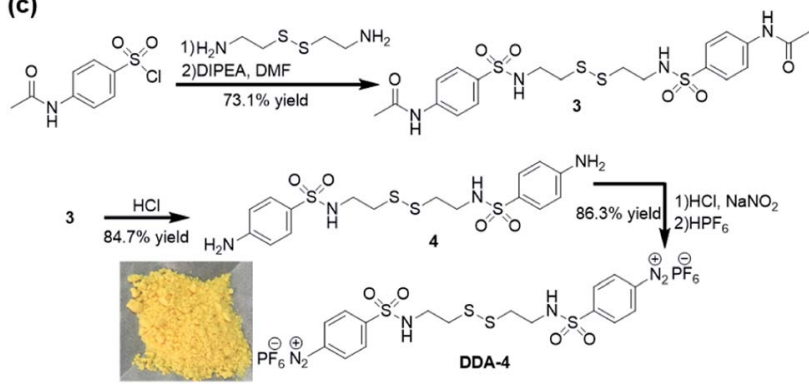

Scheme 2 The synthesis route for the dual-diazonium reagents DDA2 (a), DDA-3 (b) and DDA-4 (c). which was indirectly verified that the obtained diazonium salt was DDA-2 (see the ESI†). As for DDA-3 and DDA-4, the high chemical shift values in ${ }^{1} \mathrm{H}$ NMR compared to their aromatic amine feedstock also implied the existence of positively charged diazo moieties. All dual-diazonium hexafluorophosphates were bench-stable and could be stored in the refrigerator $\left(-20^{\circ} \mathrm{C}\right)$ for at least two months.

We firstly studied the reaction of DDA-2 or DDA-3 with Tyr using the UV-Vis spectrophotometry (Fig. 1). The timedependent absorption changes at $400 \mathrm{~nm}$ implied the formation of azo bonds ${ }^{11,12}$ and enabled us to follow the reaction kinetics conveniently. When the dual-diazonium reagent and Tyr were mixed under pseudo-first-order conditions, the absorption peak at $400 \mathrm{~nm}$ was monitored with time. The pseudo-first-order rate $k_{\text {obs }}$ was determined by fitting the data with a single exponential function. The linear fitting between $k_{\mathrm{obs}}$ and Tyr concentrations gave the reaction rate $\left(k_{2}\right)$. DDA-2 showed much smaller $k_{2}\left(18.39 \mathrm{M}^{-1} \mathrm{~s}^{-1}\right)$ than that of DDA-3 $\left(71.19 \mathrm{M}^{-1} \mathrm{~s}^{-1}\right)$, implying that the substitution of $\mathrm{CO}$ group with $\mathrm{SO}_{2}$ group greatly enhanced the reaction rate (Fig. 1, $\mathrm{S} 1$ and S2 $\uparrow$ ). Substituents linked to aromatic cycles could affect the reactivity of diazonium with Tyr due to conjugate and other effects. Herein, the Hammett equation was further used to study the relationship between the para and meta substituents

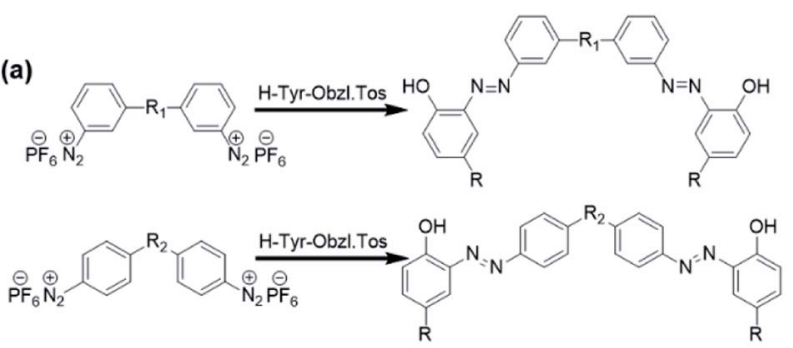

(b)

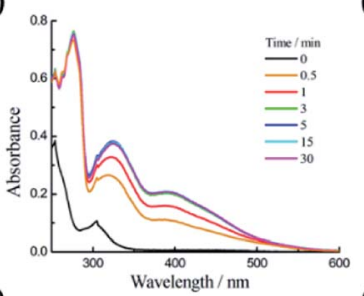

(d)

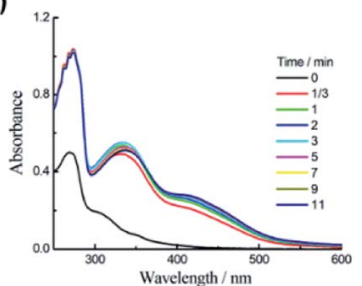

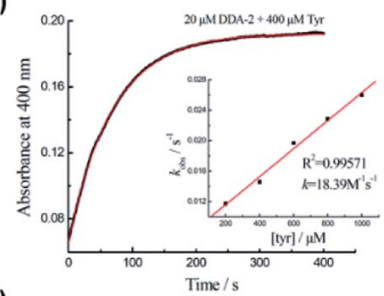

(e)

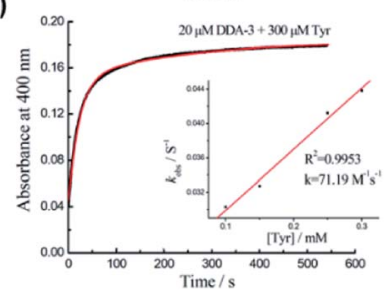

Fig. 1 Kinetic assay of dual-diazonium reagents with Tyr. (a) Azocoupling reaction of diazonium reagent with Tyr, $\mathrm{R}_{1}=\mathrm{POCH}_{3}$ (DDA-2), $\mathrm{R}_{2}=\mathrm{SO}_{2}(\mathrm{DDA}-3)$; (b) time-dependent UV-Vis absorbance spectra of DDA-2 $(20 \mu \mathrm{M})$ with Tyr $(400 \mu \mathrm{M})$; (c) time-dependent absorbance at $400 \mathrm{~nm}$ of DDA-2 with Tyr; (d) time-dependent UV-Vis absorbance spectra of DDA-3 $(20 \mu \mathrm{M})$ with Tyr $(300 \mu \mathrm{M})$; (e) time-dependent absorbance at $400 \mathrm{~nm}$ of DDA-3 with Tyr. The rate constants of the azo-coupling reactions are indicated in the inset. 
of benzene derivatives and the reaction rate. In this work, the Hammett parameter $\sigma^{\mathbf{1 3}}$ was obtained by using two kinds of similar structural substituents (Fig. S3†). ${ }^{\mathbf{1 4}}$ By comparing the reactivity of the three diazonium salts, we found that the crosslinking rate of the diazonium cations and Tyr was higher with increasing electron withdrawing of the substituent: DDA-3 > DDA-1 > DDA-2. Remarkably, the slope of the linear fit was positive, demonstrating that the electron-withdrawing substituents accelerated the reaction, which was consistent with the kinetic results. This study might help us to construct more efficient multi-diazonium reagents in the future.

To compare the efficiency of dual-diazonium reagents (DDA-1, DDA-2, DDA-3) in protein labelling, we firstly used these reagents to crosslink the capsid proteins from tobacco mosaic virus (TMV $\mathrm{CP})$ at $25^{\circ} \mathrm{C}$. The SDS-PAGE assay revealed that DDA-3 had higher crosslinking efficiency than that of DDA-1 and DDA-2 at room temperature. When the concentration of DDA-3 reached at least $1.25 \mathrm{mM}$, the percentage of crosslinked capsid proteins could be more than $85 \%$. At such concentration, DDA-1 and DDA-2 could just achieve $30-50 \%$ protein crosslinking (Fig. 2).

Subsequently, we used these reagents to crosslink TMV virus at $25{ }^{\circ} \mathrm{C}$ and $37{ }^{\circ} \mathrm{C}$. Based on SDS-PAGE analysis, we also found that the crosslinking efficiency of DDA-3 at $37{ }^{\circ} \mathrm{C}$ were slightly higher than that at $25{ }^{\circ} \mathrm{C}$ while the crosslinking efficiency of DDA-1 at $25{ }^{\circ} \mathrm{C}$ was significantly lower than that at $37{ }^{\circ} \mathrm{C}$ (Fig. S4-S6†). Furthermore, time-dependent crosslinking of TMV also suggested that the reaction could finish within $10 \mathrm{~min}$ for DDA-3 (Fig. S7 $\dagger$ ) and not finish until $60 \mathrm{~min}$ for DDA-1 (Fig. S8 $\dagger$ ) at $25{ }^{\circ} \mathrm{C}$. These results clearly demonstrated that the substitution of $\mathrm{CO}$ group with $\mathrm{SO}_{2}$ group in the linker reagent greatly enhanced the speed and efficiency of protein crosslinking and TMV crosslinking at room temperature.

Encouraging with the above results, we then employed these reagents to crosslink TMV virus matrix to construct hydrogels. We firstly performed the time- and dose-dependent gelation
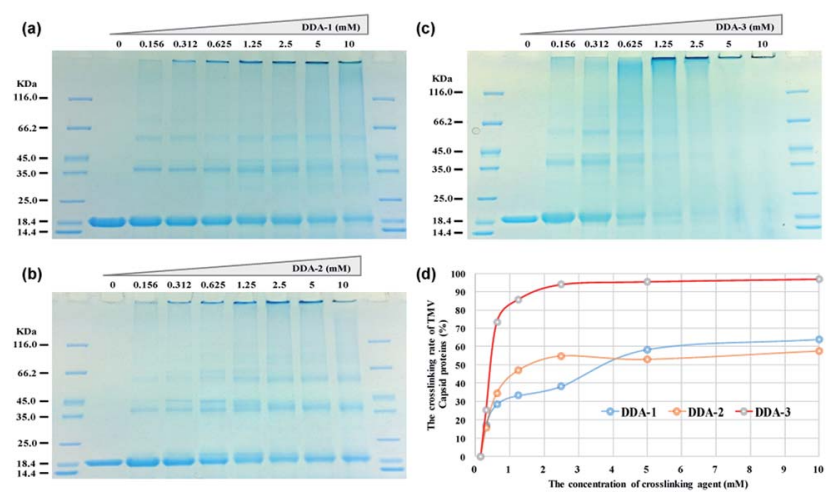

Fig. 2 The crosslinking of capsid proteins from tobacco mosaic virus with three crosslinking reagents. The dual-diazonium reagent (DDA-1, DDA-2 or DDA-3) was firstly dissolved in DMSO and then diluted to a gradient concentration $(100,50,25,12.5,6.25,3.12,1.56, \mathrm{mM})$. The reaction was performed by mixing $9 \mu \mathrm{L}$ TMV capsid proteins $\left(2 \mu \mathrm{g} \mu \mathrm{L}^{-1}\right)$ and $1 \mu \mathrm{L}$ dual-diazonium reagent with various concentrations. The reaction was incubated at $25^{\circ} \mathrm{C}$ for $30 \mathrm{~min}$. After reaction, $10 \mu \mathrm{L}$ sample for each treatment was directly used for $12 \%$ SDS-PAGE assay. tests. The results showed that $10 \mathrm{mM}$ DDA-3 could completely solidify TMV matrix $\left(2.5 \mathrm{mg} \mathrm{mL}{ }^{-1}\right)$ in $1 \mathrm{~min}$ at $25^{\circ} \mathrm{C}$. While for DDA-2, the complete gelation should cost at least 15 min under similar conditions (Fig. S9†). Therefore, we further used DDA-3 in following studies. The dose-dependent tests also suggested that $1.25 \mathrm{mM}$ DDA-3 and $1.25 \mathrm{mg} \mathrm{mL}^{-1}$ TMV matrix were the minimum concentration for gelation within $30 \mathrm{~min}$ (Fig. 3, S10 and S11 $\dagger$ ). The high concentration of crosslinker and TMV matrix like $10 \mathrm{mM}$ DDA-3 and $5 \mathrm{mg} \mathrm{mL}{ }^{-1}$ TMV matrix also provided the high solidification. These results implied that improved dual-diazonium reagents could be used for faster crosslinking of tobacco mosaic virus as hydrogels, which further simplify the gelation method.

To further probe the crosslinking efficiency, we subsequently determined the rheological characters of the hydrogels formed by TMV and DDA-2 or DDA-3 from the solution phase to gel phase. As shown in Fig. 4a, the viscosity of both hydrogels started to increase after $100 \mathrm{~s}$, while the hydrogel with DDA-3 showed higher viscosity (about 2.5-fold) than that with DDA-2, implying that DDA-3 had the higher gelation efficiency. Both the hydrogels were solidified after $400 \mathrm{~s}$. Moreover, we also analysed the storage modulus of TMV hydrogels (Fig. 4b) and found that the hydrogel based on DDA-3 had much faster gelation speed with a relatively higher storage modulus than that based on DDA-2. These results indicate that the improved reagent DDA-3 could be used for faster crosslinking of TMV as hydrogels than DDA-2.

We further used scanning electron microscope (SEM) to analyze the structure of TMV hydrogels from $10 \mathrm{mM}$ DDA-2 or DDA-3 and $5 \mathrm{mg} \mathrm{mL} \mathrm{mL}^{-1}$ TMV. SEM results showed multiple virus

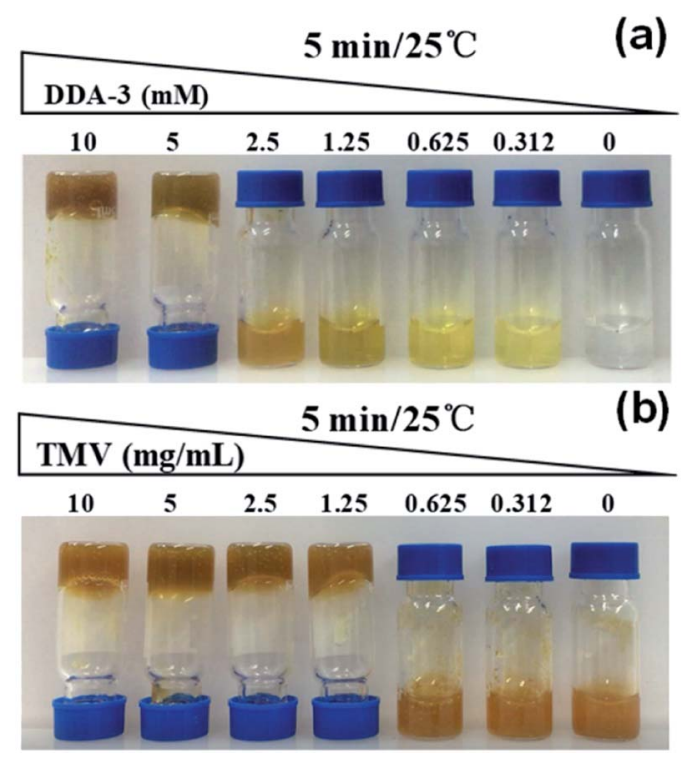

Fig. 3 Dose-dependent TMV gelation. (a) The effect of the concentration of DDA-3 on TMV gelation. The final concentration of DDA-3 was varying from $0-10 \mathrm{mM}$ and the concentration of TMV matrix was $2.5 \mathrm{mg} \mathrm{mL}^{-1}$. (b) The effect of the concentration of TMV matrix on TMV gelation. The final concentration of TMV matrix was varying from $0-$ $10 \mathrm{mg} \mathrm{mL}^{-1}$ and the concentration of DDA-3 was $10 \mathrm{mM}$. The gelation time was kept within 5 min at room temperature. 

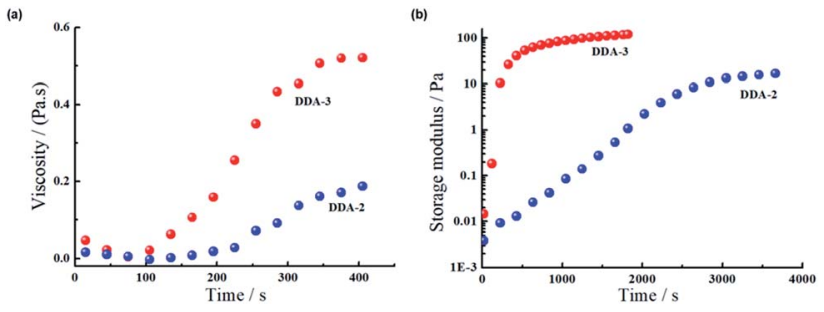

Fig. 4 Rheological characters of TMV hydrogels. (a) The viscosity of TMV hydrogels with DDA-2 or DDA-3 was measured within $400 \mathrm{~s}$ at $25^{\circ} \mathrm{C}$ at a shear rate of $1 \mathrm{~s}^{-1}$. (b) The storage modulus of TMV hydrogels with DDA-2 or DDA-3 was measured within $4000 \mathrm{~s}$ at $25^{\circ} \mathrm{C}$. The scanning strain value and the oscillation frequency were set as $1 \%$ and $0.1 \mathrm{~Hz}$, respectively.

rods in DDA-2 constructed hydrogel was crosslinked to form the 3D net structure, while a large number of sheets and less net structure were observed in DDA-3 constructed hydrogel (Fig. 5).

Considering the importance of biocompatibility and degradability of hydrogels in applications, we also synthesized DDA-4 through introducing a disulfide bond on the basis of DDA-3. The DDA-4 has similar ability as DDA-3 for TMV gelation (Fig. S9†). We then used the TMV hydrogels with DDA-4 to make the capital "BUCT" and "NKU" in the dish (Fig. 6), and determined whether the hydrogels could be degraded by reducing chemicals like DTT. After the gelation, we immersed the gel in the DTT solution (500 $\mathrm{mM}$ ) and observed the degradation of the gel within $8 \mathrm{~h}$, suggesting the disulfide bond was gradually cleaved by DTT (Fig. 6 and $\mathrm{S} 12 \dagger)$. On the contrary, the same hydrogel in the dish was not affected when no DTT was added. We believe that this kind of disulfide bond-based hydrogel could be disrupted by reducing

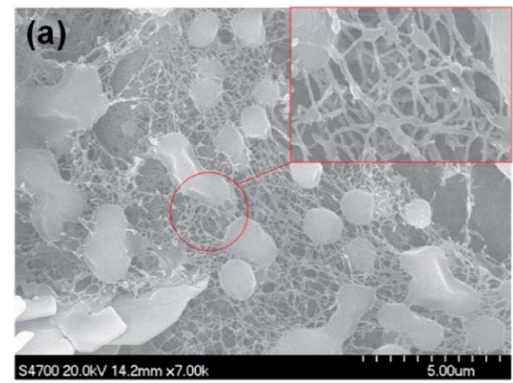

TMV hydrogel with DDA-2

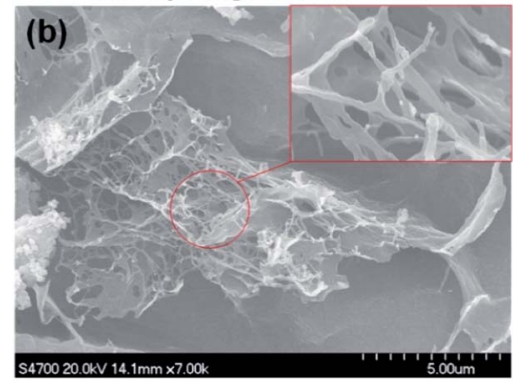

TMV hydrogel with DDA-3

Fig. 5 Characterization of the TMV hydrogel with DDA-2 (a) and DDA3 (b) by SEM. Scale bar, $500 \mu \mathrm{m}$ for full view and $500 \mathrm{~nm}$ for the red rectangular box.

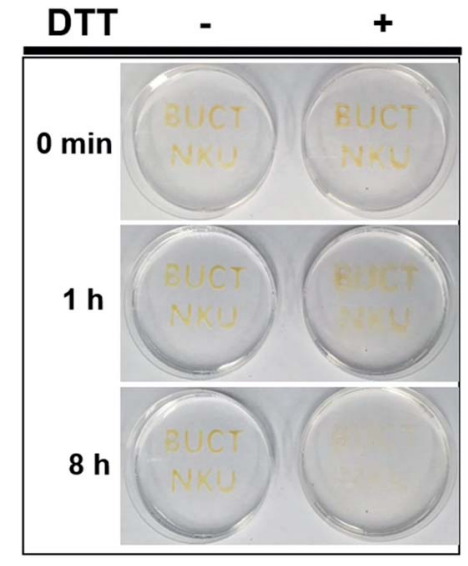

Fig. 6 TMV hydrogel degradation with dithiothreitol (DTT). The capital "BUCT" and "NKU" were made from TMV hydrogel crosslinked with DDA-4 on the Petri dish. After gelation, the TMV hydrogel was immersed with $20 \mathrm{~mL}$ DTT $(500 \mathrm{mM})$ or $20 \mathrm{~mL}$ deionized water. The gel degradation was imaged at different time (0 min, $1 \mathrm{~h}, 8 \mathrm{~h}$ ).

molecules in vivo, which might add its biocompatibility for chemically controlled disassembly. ${ }^{15}$

\section{Conclusions}

To improve the reaction rate and gelation efficiency, we developed new bench-stable reagents with different substituents (CO, PO, $\mathrm{SO}_{2}$ ) between two diazonium sites. Through comparing the reaction rate constant and protein crosslinking efficiency, we found that DDA-3 greatly improved the crosslinking efficiency and also shortened the gelation time even at room temperate, which was a great improvement compared with DDA-1. ${ }^{11}$ The SDS-PAGE and SEM characterizations also confirmed the virus crosslinking via the dual-diazonium reagents. Furthermore, hydrogels with the introduction of disulfide bonds via DDA-4 could be chemically degraded by biocompatible reducing molecules. We propose that the new dual-diazonium reagents may provide a general approach to preparing diverse functional hydrogels from other biocompatible viruses for future biomedical applications.

\section{Experimental}

\section{General}

All chemicals and solvents used for synthesis were purchased from commercial suppliers and applied directly in the experiments without further purification. The progress of the reaction was monitored by TLC on pre-coated silica plates (Merck 60F-254, 250 $\mu \mathrm{m}$ in thickness), and spots were visualized by UV light (254 nm). Merck silica gel (100-200 mesh) was used for general column chromatography purification. ${ }^{1} \mathrm{H}$ NMR and ${ }^{13} \mathrm{C}$ NMR spectra were recorded on a Bruker 400 spectrometer. Chemical shifts are reported in parts per million relative to internal standard tetramethylsilane $\left(\mathrm{Si}\left(\mathrm{CH}_{3}\right)_{4}=0.00 \mathrm{ppm}\right)$ or residual solvent peaks (DMSO$\left.d_{6}=2.50 \mathrm{ppm},{ }^{1} \mathrm{H} ; 39.52 \mathrm{ppm},{ }^{13} \mathrm{C}\right) .{ }^{1} \mathrm{H}$ NMR coupling constants $(J)$ are reported in hertz $(\mathrm{Hz})$, and multiplicity is indicated as the 
following: $s$ (singlet), d (doublet), t (triplet), q (quartet), td (triplet doublet), dd (doublet of doublets), m (multiple). High-resolution mass spectra (HRMS) were obtained on an Agilent 6540 UHD Accurate-Mass Q-TOFLC/MS. The UV-Visible spectra were recorded on a UV-6000 UV-VIS-NIR-spectrophotometer (METASH, China).

\section{Synthesis of DDA-2}

Methyl diphenyl phosphine oxide (4.89 g, $22.6 \mathrm{mmol}$ ) was dissolved in concentrated sulfuric acid $(20 \mathrm{~mL})$, and stirred under ice-cooling to dissolve the solid. A mixture of concentrated sulfuric acid $(20 \mathrm{~mL})$ and concentrated nitric acid $(20 \mathrm{~mL})$ was slowly added dropwise with a dropper. After the addition was completed, the ice bath was removed and the mixture was stirred at room temperature overnight. The reaction was monitored by TLC $\left(\mathrm{CH}_{2} \mathrm{Cl}_{2}: \mathrm{MeOH}=19: 1\right)$. The reaction mixture was poured into ice water and then the precipitated solid were collected by filtration. After being washed with saturated aqueous $\mathrm{NaHCO}_{3}$ until neutral $\mathrm{pH}$, the product was recrystallized with absolute ethanol, yielding a light-yellow solid of $1(4.74 \mathrm{~g}, 68.5 \%) .{ }^{1} \mathrm{H}$ NMR (400 MHz, DMSO- $\left.d_{6}\right) \delta 8.61(\mathrm{~d}, J=$ $12.0 \mathrm{~Hz}, 2 \mathrm{H}), 8.41(\mathrm{~d}, J=8.1 \mathrm{~Hz}, 2 \mathrm{H}), 8.29(\mathrm{dd}, 2 \mathrm{H}), 7.85(\mathrm{td}, J=$ 7.9, $2.6 \mathrm{~Hz}, 2 \mathrm{H}), 2.31$ (d, $J=14.1 \mathrm{~Hz}, 3 \mathrm{H}) ;{ }^{13} \mathrm{C}$ NMR $(101 \mathrm{MHz}$, DMSO- $\left.d_{6}\right) \delta 148.0,147.8,137.0,136.7,136.6,136.0,130.8,130.7$, 126.7, 126.7, 125.0, 124.9, 15.6, 14.9.

Tin II chloride (14.48 g, $64.2 \mathrm{mmol}$ ) was dissolved in $40 \mathrm{~mL}$ concentrated HCl. 1 (3.11 g, $10.1 \mathrm{mmol})$ was added portionwise with stirring and the reaction mixture was refluxed at $80{ }^{\circ} \mathrm{C}$ for $2 \mathrm{~h}$. After the mixture had cooled to room temperature, the $\mathrm{pH}$ of the mixture was adjusted to $9-10$ by the saturated solution of $\mathrm{NaOH}$ at $0{ }^{\circ} \mathrm{C}$. The mixture was extracted with EtOAc. The organic phase was washed by brine and dried over anhydrous $\mathrm{Na}_{2} \mathrm{SO}_{4}$. After removing the solvent under reduced pressure, the product was purified by silica gel column chromatography to give $2(2.15 \mathrm{~g}, 86.4 \%) .{ }^{1} \mathrm{H}$ NMR $\left(400 \mathrm{MHz}, \mathrm{DMSO}-d_{6}\right) \delta 7.11(\mathrm{td}, J$ $=7.7,3.6 \mathrm{~Hz}, 2 \mathrm{H}), 6.89(\mathrm{~d}, J=13.1 \mathrm{~Hz}, 2 \mathrm{H}), 6.78(\mathrm{dd}, J=11.1$, $7.6 \mathrm{~Hz}, 2 \mathrm{H}), 6.67$ (d, $J=7.9 \mathrm{~Hz}, 2 \mathrm{H}), 5.31(\mathrm{~s}, 4 \mathrm{H}), 1.81$ (d, $J=$ $13.1 \mathrm{~Hz}, 3 \mathrm{H}) ;{ }^{13} \mathrm{C}$ NMR (101 MHz, DMSO- $\left.d_{6}\right) \delta$ 148.8, 148.6, 136.2, 135.2, 129.1, 128.9, 117.1, 117.0, 116.4, 116.4, 115.2, $115.1,16.4,15.6 ;{ }^{31} \mathrm{P}$ NMR (162 MHz, DMSO- $\left.d_{6}\right) \delta 28.63(\mathrm{~s})$.

$2(998 \mathrm{mg}, 4.0 \mathrm{mmol})$ was dissolved in $30 \mathrm{~mL}$ cold concentrated $\mathrm{HCl}$ and cooled down to $0{ }^{\circ} \mathrm{C}$. The water solution of $\mathrm{NaNO}_{2}(1.82 \mathrm{~g}, 26.4 \mathrm{mmol})$ was slowly added to the mixture at $0{ }^{\circ} \mathrm{C}$. After reaction for $30 \mathrm{~min}, 4 \mathrm{~mL} 60 \% \mathrm{HPF}_{6}$ was added and the mixture was stirred for $1 \mathrm{~h}$. The product was collected by filtration and washed by ice-cold water, yielding a creamy-white solid of DDA-2 (1.34 g, 59.8\%). ${ }^{1} \mathrm{H}$ NMR (400 MHz, DMSO- $d_{6}$ ) $\delta 9.19(\mathrm{~d}, J=11.5 \mathrm{~Hz}, 2 \mathrm{H}), 8.86(\mathrm{~d}, J=8.2 \mathrm{~Hz}, 2 \mathrm{H}), 8.63(\mathrm{t}, 2 \mathrm{H})$, $8.17(\mathrm{t}, J=7.6 \mathrm{~Hz}, 2 \mathrm{H}), 2.36(\mathrm{~d}, J=14.2 \mathrm{~Hz}, 3 \mathrm{H}) ;{ }^{13} \mathrm{C}$ NMR $(101$ MHz, DMSO- $\left.d_{6}\right) \delta 141.7,141.6,137.3,136.4,135.9,135.1,135.0$, 132.0, 131.9, 118.0, 117.8, 15.5, 14.8; ${ }^{31}$ P NMR (162 MHz, DMSO$\left.d_{6}\right) \delta 26.52(\mathrm{~s}),-144.20\left(\mathrm{~h}, J_{\mathrm{P}-\mathrm{F}}=711.3 \mathrm{~Hz}\right)$.

\section{Synthesis of DDA-3}

4,4'-Diaminodiphenyl sulfone (1.16 g, $4.6 \mathrm{mmol})$ was dissolved in $20 \mathrm{~mL}$ concentrated $\mathrm{HCl}$ and $40 \mathrm{~mL} \mathrm{H}_{2} \mathrm{O}$ and cooled down to $0{ }^{\circ} \mathrm{C}$. The water solution of $\mathrm{NaNO}_{2}(2.07 \mathrm{~g}, 29.6 \mathrm{mmol})$ was slowly added to the mixture at $0{ }^{\circ} \mathrm{C}$. After reaction for $1 \mathrm{~h}, 4 \mathrm{~mL}$ $60 \% \mathrm{HPF}_{6}$ was added and the mixture was stirred for $1 \mathrm{~h}$. The product was collected by filtration and washed with methanol and dichloromethane, yielding a yellow solid of DDA-3 (2.01 g, $77.7 \%) .{ }^{1} \mathrm{H}$ NMR (400 MHz, DMSO- $\left.d_{6}\right) \delta 8.94(\mathrm{~d}, J=8.8 \mathrm{~Hz}, 4 \mathrm{H})$, $8.65(\mathrm{~d}, J=8.8 \mathrm{~Hz}, 4 \mathrm{H}) ;{ }^{13} \mathrm{C}$ NMR (101 MHz, DMSO- $\left.d_{6}\right) \delta 147.6$, 134.3, 130.6, 122.9; ${ }^{31} \mathrm{P}$ NMR (162 MHz, DMSO- $\left.d_{6}\right) \delta-144.19$ (h, $\left.J_{\mathrm{P}-\mathrm{F}}=711.3 \mathrm{~Hz}\right)$.

\section{Synthesis of DDA-4}

Cystamine dihydrochloride $(0.99 \mathrm{~g}, 4.4 \mathrm{mmol})$ and 4 -acetamidobenzenesulfonyl chloride $(2.48 \mathrm{~g}, 10.6 \mathrm{mmol})$ was dissolved in $10 \mathrm{~mL}$ DMF. The mixture was stirred at $0{ }^{\circ} \mathrm{C}$; DIPEA (3.4 mL, $20.0 \mathrm{mmol}$ ) was added into $10 \mathrm{~mL} \mathrm{DMF}$ and add in batches with a syringe in portions at $0{ }^{\circ} \mathrm{C}$. The mixture was stirred at room temperature overnight. The solvent was evaporated under reduced pressure and the crude was diluted with $50 \mathrm{~mL}$ dichloromethane. The product was collected by filtration and washed with dichloromethane to give 3 (1.76 g, 73.1\%). ${ }^{1} \mathrm{H}$ NMR (400 MHz, DMSO- $\left.d_{6}\right) \delta 10.32(\mathrm{~s}, 1 \mathrm{H}), 7.78-7.67(\mathrm{~m}, 2 \mathrm{H})$, $2.98(\mathrm{q}, J=13.1,6.5 \mathrm{~Hz}, 1 \mathrm{H}), 2.66(\mathrm{t}, J=6.9 \mathrm{~Hz}, 1 \mathrm{H}), 2.08(\mathrm{~s}, 1 \mathrm{H})$; ${ }^{13} \mathrm{C}$ NMR (101 MHz, DMSO- $\left.d_{6}\right) \delta 169.0,142.8,133.9,127.7$, 118.7, 41.7, 37.0, 24.1.

$3(1.16 \mathrm{~g}, 2.1 \mathrm{mmol})$ was dissolved in $40 \mathrm{~mL}$ concentrated $\mathrm{HCl}$, and the mixture was stirred at $60{ }^{\circ} \mathrm{C}$ for $4 \mathrm{~h}$. Then it was collected by filtration and the saturated solution of $\mathrm{NaHCO}_{3}$ was added until pH 7-8. Next, the mixture was extracted with EtOAc, and the combined organic extracts were washed with brine, dried over anhydrous $\mathrm{Na}_{2} \mathrm{SO}_{4}$, and evaporated under reduced pressure. The product was purified by silica gel column chromatography $\left(\mathrm{CH}_{2} \mathrm{Cl}_{2}: \mathrm{MeOH}=95: 5\right)$ to give $4(823 \mathrm{mg}, 84.7 \%)$. ${ }^{1} \mathrm{H}$ NMR (400 MHz, DMSO- $\left.d_{6}\right) \delta 7.41(\mathrm{t}, J=5.6 \mathrm{~Hz}, 1 \mathrm{H}), 7.29(\mathrm{t}, J$ $=5.9 \mathrm{~Hz}, 1 \mathrm{H}), 6.63-6.59(\mathrm{~m}, 1 \mathrm{H}), 5.93(\mathrm{~s}, 1 \mathrm{H}), 2.92(\mathrm{dd}, J=13.7$, $6.2 \mathrm{~Hz}, 1 \mathrm{H}), 2.65(\mathrm{t}, J=7.0 \mathrm{~Hz}, 1 \mathrm{H}) ;{ }^{13} \mathrm{C}$ NMR (101 MHz, DMSO$\left.d_{6}\right) \delta 152.6,128.5,125.2,112.7,41.8,37.0$. HRMS (ESI): $m / z[\mathrm{M}+$ $\mathrm{H}]^{+}$calculated for $\mathrm{C}_{16} \mathrm{H}_{23} \mathrm{~N}_{4} \mathrm{O}_{4} \mathrm{~S}_{4}^{+}$: 463.0597; found: 463.0597 .

$4(523 \mathrm{mg}, 1.1 \mathrm{mmol})$ was dissolved in $20 \mathrm{~mL}$ concentrated $\mathrm{HCl}$ and $20 \mathrm{~mL} \mathrm{H}_{2} \mathrm{O}$ and cooled down to $0{ }^{\circ} \mathrm{C}$. The water solution of $\mathrm{NaNO}_{2}(483 \mathrm{mg}, 7.0 \mathrm{mmol})$ was slowly added to the mixture at $0{ }^{\circ} \mathrm{C}$. After reaction for $1 \mathrm{~h}, 2 \mathrm{~mL} 60 \% \mathrm{HPF}_{6}$ was added and the mixture was stirred for $1 \mathrm{~h}$. The product was collected by filtration and washed with ice-cold water, yielding a yellow solid of DDA-4 (741 mg, 86.3\%). ${ }^{1} \mathrm{H}$ NMR $(400 \mathrm{MHz}$, DMSO- $\left.d_{6}\right) \delta 8.87(\mathrm{~d}, 4 \mathrm{H}), 8.60(\mathrm{t}, J=5.6 \mathrm{~Hz}, 2 \mathrm{H}), 8.33(\mathrm{~d}, 4 \mathrm{H})$, $3.16(\mathrm{dd}, J=12.6,6.4 \mathrm{~Hz}, 4 \mathrm{H}), 2.75(\mathrm{t}, J=6.7 \mathrm{~Hz}, 4 \mathrm{H}) ;{ }^{13} \mathrm{C} \mathrm{NMR}$ $\left(101 \mathrm{MHz}, \mathrm{DMSO}-d_{6}\right) \delta 150.3,134.1,128.7,120.0,41.7,37.1 ;{ }^{31} \mathrm{P}$ NMR (162 MHz, DMSO- $\left.d_{6}\right) \delta-144.19\left(\mathrm{~h}, J_{\mathrm{P}-\mathrm{F}}=711.3 \mathrm{~Hz}\right)$.

\section{UV-Vis spectrophotometry assay}

All spectroscopic measurements were performed in phosphatebuffered saline buffer (50 mM, pH 7.4, containing 5\% DMSO) in a $3 \mathrm{~mL}$ corvette with $2 \mathrm{~mL}$ solution. Compounds were dissolved into DMSO to prepare the stock solutions with a concentration of $200 \mathrm{mM}$ Tyr or $20 \mathrm{mM}$ diazonium reagent.

Reaction of the diazonium reagent (DDA-2 or DDA-3) and Tyr-containing molecule (H-Tyr-OBzl Tos): $2 \mu$ L DDA-2 or DDA-3 
and $4 \mu \mathrm{L}$ Tyr was added to $1994 \mu \mathrm{L}$ buffer. The progress of the reaction was monitored by UV-Vis spectrophotometry from 250 to $600 \mathrm{~nm}$.

Determination of the kinetic parameters of the reaction between the diazonium reagent (DDA-2 or DDA-3) and tyrosine: the reaction rate was measured under pseudo-first order conditions, where $20 \mu \mathrm{M}$ DDA-2 or DDA-3 was mixed with an excess of tyrosine (0.1-1 mM) in PBS buffer (50 mM, pH 7.4, containing $5 \% \mathrm{DMSO}$ ) and the absorption at $400 \mathrm{~nm}$ was recorded per second.

\section{TMV and TMV CP purification}

According to our previous procedure, TMV virus and TMV capsid proteins were purified. ${ }^{\mathbf{1 2 a}}$

TMV purification: TMV-inoculated tobacco leaves were ground fully and mixed in $25 \mathrm{~mL} 0.2 \mathrm{M}$ phosphate buffer $(\mathrm{pH}$ 7.0) including $250 \mu \mathrm{L} \beta$-mercaptoethanol $(1 \%, \mathrm{v} / \mathrm{v})$ on ice. After the filtration with two-layer screen cloth, the clear lysates were mixed with $n$-butyl alcohol $(8 \%, \mathrm{v} / \mathrm{v})$ for $15 \mathrm{~min}$. After centrifugation at $10000 \times g$ for $20 \mathrm{~min}$, the precipitate was dissolved again with $2 \mathrm{~mL} 0.01 \mathrm{M}$ phosphate buffer $(\mathrm{pH} 7.0)$ on ice and stirred for $6 \mathrm{~h}$. After centrifugation at $10000 \times g$ for $20 \mathrm{~min}$, the pellet was resuspended in $5 \mathrm{~mL} 0.01 \mathrm{M}$ phosphate buffer $(\mathrm{pH}$ 7.0) for $2 \mathrm{~h}$. After centrifugation at $10000 \times g$ for $20 \mathrm{~min}$, the supernatant was then added with $\mathrm{NaCl}(4 \%, \mathrm{w} / \mathrm{v})$ and PEG6000 $(4 \%, \mathrm{w} / \mathrm{v})$ for overnight precipitation. After centrifugation at $10000 \times g$ for $20 \mathrm{~min}$, the precipitate was resuspended in $2 \mathrm{~mL}$ $0.01 \mathrm{M}$ phosphate buffer ( $\mathrm{pH} 7.0$ ) for $6 \mathrm{~h}$. After centrifugation at $10000 \times g$ for $5 \mathrm{~min}$, the final virus suspension was obtained and the virus purity was evaluated according to the indicated ratio of $A_{280} / A_{260}(0.84)$ and $A_{260} / A_{248}$ (1.09). TMV concentration was calculated according to $\mathrm{C}\left(\mathrm{mg} \mathrm{mL}^{-1}\right)=A_{260} / 3.1$. TMV solution was stored at $4{ }^{\circ} \mathrm{C}$ for the following test.

Purification of TMV capsid proteins (TMV CP): TMV solution was firstly diluted to $5 \mathrm{mg} \mathrm{mL}^{-1}$ and then stirred with two volumes of glacial acetic acid for $2 \mathrm{~h}$ at $4{ }^{\circ} \mathrm{C}$. Subsequently, an equal volume of sterile water was added and all the liquid was then transferred into the dialysis bag. After three to five times of water exchange, TMV CP precipitated. After centrifugation at $12000 \mathrm{rpm}$ for $30 \mathrm{~min}$, TMV CP precipitate was obtained and dissolved in $50 \mu \mathrm{L} 0.1 \mathrm{M}$ phosphate buffer ( $\mathrm{pH}$ 7.0). The concentration of TMV CP was calculated according to $\mathrm{C}(\mathrm{mg}$ $\left.\mathrm{mL}^{-1}\right)=A_{282} / 1.27$. TMV CP was stored at $4{ }^{\circ} \mathrm{C}$ for the following test.

\section{Crosslinking TMV CP and TMV virus with the dual-diazonium reagent}

TMV CP crosslinking: TMV CP crosslinking was performed by mixing TMV CP with various concentrations of the dualdiazonium reagent (DDA-1, DDA-2, DDA-3). The dualdiazonium reagent was diluted to a gradient concentration $(100,50,25,12.5,6.25,3.12,1.56, \mathrm{mM})$. The reaction was performed by mixing $9 \mu \mathrm{L}$ TMV CP $\left(2 \mu \mathrm{g} \mu \mathrm{L}^{-1}\right)$ and $1 \mu \mathrm{L}$ the dualdiazonium reagent $(100,50,25,12.5,6.25,3.12,1.56, \mathrm{mM})$. The reaction was incubated at $25{ }^{\circ} \mathrm{C}$ for $30 \mathrm{~min}$.
TMV virus crosslinking: TMV virus crosslinking was performed by mixing TMV virus with various concentrations of the dual-diazonium reagent (DDA-1, DDA-2, DDA-3). The dualdiazonium reagent was diluted to a gradient concentration $(100,50,25,12.5,6.25,3.12,1.56, \mathrm{mM})$. The reaction was performed by mixing $9 \mu \mathrm{L}$ TMV virus $\left(1 \mu \mathrm{g} \mu \mathrm{L}^{-1}\right)$ and $1 \mu \mathrm{L}$ the dualdiazonium reagent $(100,50,25,12.5,6.25,3.12,1.56, \mathrm{mM})$. The reaction was incubated at $25^{\circ} \mathrm{C}$ or $37{ }^{\circ} \mathrm{C}$ for $30 \mathrm{~min}$ or $60 \mathrm{~min}$.

After reaction, all samples were mixed with $5 \times$ SDS loading buffer and used for $12 \%$ SDS-PAGE assay. The SDS-PAGE gel was stained with Coomassie blue R250 and imaged with Quantity One software (Bio-Rad).

\section{Construction of TMV hydrogel with the dual-diazonium reagent}

To optimize conditions for hydrogel preparation, we tried different concentrations of TMV matrix $\left(0-10 \mathrm{mg} \mathrm{mL}^{-1}\right)$ and DDA-3 (0-10 mM). TMV hydrogel was made by gently mixing different concentrations of DDA-3 and TMV solution in a glass vial at room temperature for $0-30 \mathrm{~min}$ to evaluate the gelation condition.

For TMV hydrogel with $2.5 \mathrm{mg} \mathrm{mL}^{-1}$ TMV matrix and $10 \mathrm{mM}$ DDA-2 or DDA-3, DDA-2 or DDA-3 was freshly prepared in DMSO as $100 \mathrm{mM}$ stock solution. $50 \mu \mathrm{L}$ of DDA-2 or DDA-3 $(100 \mathrm{mM})$ was added to $325 \mu \mathrm{L}$ of $0.1 \mathrm{M}$ phosphate buffer $(\mathrm{pH} 7.0)$ to prepare solution A; $62.5 \mu \mathrm{L}$ of TMV solution $\left(20 \mathrm{mg} \mathrm{mL}^{-1}\right)$ was added to $62.5 \mu \mathrm{L}$ of phosphate buffer to prepare solution $\mathrm{B}$. The reaction was performed by mixing solution A and solution $\mathrm{B}$. The gelation of TMV hydrogel was observed within $30 \mathrm{~min}$ at room temperature. It was the same for DDA-4 constructed hydrogel except that the concentration of DDA-4 and TMV matrix were $2 \mathrm{mM}$ and $2.5 \mathrm{mg} \mathrm{mL}^{-1}$, respectively.

\section{Scanning electron microscopy (SEM) characterization}

TMV hydrogel was made by $5 \mathrm{mg} \mathrm{mL}^{-1}$ TMV and $10 \mathrm{mM}$ DDA-2 or DDA-3 at room temperature for $1 \mathrm{~h}$. Then, the hydrogel was firstly cold-dried and loaded onto the sample vessel. The sample was imaged using a Hitachi S-4700 field emission SEM.

\section{Rheology}

All rheological measurements were performed using an ar2000ex Rheometer from TA Instruments at $25{ }^{\circ} \mathrm{C}$. When the crosslinking reagent and the TMV solution were mixed, the mixture was quickly added to the mold to start testing before the hydrogel was completely solidified. TMV hydrogel was made by $2.5 \mathrm{mg} \mathrm{mL}{ }^{-1} \mathrm{TMV}$ and $10 \mathrm{mM}$ DDA-2 or DDA-3. Due to the faster rate of DDA-3 crosslinking, we formulated this hydrogel in ice-water bath conditions.

\section{TMV hydrogel degradation}

To degrade virus hydrogel with chemical agents, TMV hydrogel was made according to the above procedure with DDA-4. The TMV hydrogel was degraded by dithiothreitol (DTT). We firstly carved the word "BUCT" and "NKU" on the Petri dish. The hydrogel was made by transferring the mixture of $2.5 \mathrm{mg} \mathrm{mL}^{-1}$ 
TMV and 2 mM DDA-4 on the word groove for gelation at room temperature. After gelation, $20 \mathrm{~mL}$ DTT $(500 \mathrm{mM})$ as the test group and $20 \mathrm{~mL}$ deionized water as the control group were transferred into the Petri dish to immerse the TMV hydrogel. The gel degradation was imaged at different time (0-12 h).

\section{Conflicts of interest}

There are no conflicts to declare.

\section{Acknowledgements}

This work was supported by NSFC (21572019) and Beijing Municipal Natural Science Foundation (2192038).

\section{Notes and references}

1 (a) S. R. Caliari and J. A. Burdick, Nat. Methods, 2016, 13, 405414; (b) K. T. Dicker, J. Song, A. C. Moore, H. Zhang, Y. Li, D. L. Burris, X. Jia and J. M. Fox, Chem. Sci., 2018, 9, 53945404; (c) O. Chaudhuri, Biomater. Sci., 2017, 5, 1480-1490; (d) S. J. Kim, J. Park, H. Byun, Y. W. Park, L. G. Major, D. Y. Lee, Y. S. Choi and H. Shin, Biomaterials, 2019, 188, 198-212; (e) M. W. Tibbitt and K. S. Anseth, Biotechnol. Bioeng., 2009, 103, 655-663; (f) T. Bai, A. Sinclair, F. Sun, P. Jain, H.-C. Hung, P. Zhang, J.-R. Ella-Menye, W. Liu and S. Jiang, Chem. Sci., 2016, 7, 333-338.

2 (a) J. Xing, M. Zheng and X. Duan, Chem. Soc. Rev., 2015, 44, 5031-5039; (b) X. Mao, G. Chen, Z. Wang, Y. Zhang, X. Zhu and G. Li, Chem. Sci., 2018, 9, 811-818; (c) B. Balakrishnan and R. Banerjee, Chem. Rev., 2011, 111, 4453-4474; (d) S. Reakasame and A. R. Boccaccini, Biomacromolecules, 2018, 19, 3-21; (e) M. Mehrali, A. Thakur, C. P. Pennisi, S. Talebian, A. Arpanaei, M. Nikkhah and A. DolatshahiPirouz, Adv. Mater., 2017, 29, 1603612; (f) A. Brito, Y. M. Abul-Haija, D. S. da Costa, R. Novoa-Carballal, R. L. Reis, R. V. Ulijn, R. A. Pires and I. Pashkuleva, Chem. Sci., 2019, 10, 2385-2390; (g) Y. P. Singh, J. C. Moses, N. Bhardwaj and B. B. Madal, J. Mater. Chem. B, 2018, 6, 5499-5529.

3 (a) S. Merino, C. Martin, K. Kostarelos, M. Prato and E. Vazquez, ACS Nano, 2015, 9, 4686-4697; (b) J. Tsai, T. Zou, J. Liu, T. Chen, A. Chan, C. Yang, C. Lok and C. Che, Chem. Sci., 2015, 6, 3823-3830; (c) J. Xing, M. Zheng and X. Duan, Chem. Soc. Rev., 2015, 44, 50315039; (d) M. R. Saboktakin and R. M. Tabatabaei, Int. J. Biol. Macromol., 2015, 75, 426-436; (e) R. Dimatteo, N. J. Darling and T. Segura, Adv. Drug Delivery Rev., 2018, 127, 167-184; (f) T. Su, Z. Tang, H. He, W. Li, X. Wang, C. Liao, Y. Sun and Q. Wang, Chem. Sci., 2014, 5, 42044209; $(g)$ B. D. Monnery and R. Hoogenboom, Polym. Chem., 2019, 10, 3480-3487.

4 (a) D. Stern and H. Cui, Adv. Healthcare Mater., 2019, 8, e1900104; (b) G. M. Guebitz and G. S. Nyanhongo, Trends Biotechnol., 2018, 36, 1040-1053; (c) Q. Xu, L. Guo, A. Sigen, Y. Gao, D. Zhou, U. Greiser, J. Creagh-Flynn, H. Zhang, Y. Dong, L. Cutlar, F. Wang, W. Liu, W. Wang and W. Wang, Chem. Sci., 2018, 9, 2179-2187; (d) A. H. Morris, H. Lee, H. Xing, D. K. Stamer, M. Tan and T. R. Kyriakides, ACS Appl. Mater. Interfaces, 2018, 10, 41892-41901; (e) X. Chen, Z. Yue, P. C. Winberg, J. N. Dinoro, P. Hayes, S. Beirne and G. G. Wallace, Biomater. Sci., 2019, 10, 41892-41901; (f) S. An, E. J. Jeon, J. Jeon and S. Cho, Mater. Horiz., 2019, 6, 1169-1178; $(g)$ H. Jiang, M. Ochoa, J. F. Waimin, R. Rahimi and B. Ziaie, Lab Chip, 2019, 19, 2265-2274.

5 (a) E. M. Ahmed, J. Adv. Res., 2015, 6, 105-121; (b) H. Yuk, B. Lu and X. Zhao, Chem. Soc. Rev., 2019, 48, 1642-1667; (c) X. Le, W. Lu, J. Zheng, D. Tong, N. Zhao, C. Ma, H. Xiao, J. Zhang, Y. Huang and T. Chen, Chem. Sci., 2016, 7, 67156720; (d) T. E. Brown and K. S. Anseth, Chem. Soc. Rev., 2017, 46, 6532-6552; (e) S. An, E. J. Jeon, J. Jeon and S. Cho, Mater. Horiz., 2019, 6, 1169-1178.

6 (a) Y. Zhu, Q. Zhang, X. Shi and D. Han, Adv. Mater., 2019, e1804950; (b) C. Chen, L. Wang, L. Deng, R. Hu and A. Dong, J. Biomed. Mater. Res., Part A, 2013, 101, 684-693; (c) S. De Koker, J. Cui, N. Vanparijs, L. Albertazzi, J. Grooten, F. Caruso and B. G. De Geest, Angew. Chem., Int. Ed., 2016, 55, 1334-1339; (d) C. Wang, M. Fadeev, J. Zhang, M. Vázquez-González, G. Davidson-Rozenfeld, H. Tian and I. Willner, Chem. Sci., 2018, 9, 7145-7152; (e) Y. Wang, Y. Li, X. Yu, Q. Long and T. Zhang, RSC Adv., 2019, 9, 18394-18405; (f) J. Du, S. Xu, S. Feng, L. Yu, J. Wang and Y. Liu, Soft Matter, 2016, 12, 1649-1654.

7 (a) A. M. Wen and N. F. Steinmetz, Chem. Soc. Rev., 2016, 45, 4074-4126; (b) T. L. Schlick, Z. Ding, E. W. Kovacs and M. B. Francis, J. Am. Chem. Soc., 2005, 127, 3718-3723; (c) K. Mohan and G. A. Weiss, ACS Chem. Biol., 2016, 11, 1167-1179; (d) Z. Liu, J. Qiao, Z. Niu and Q. Wang, Chem. Soc. Rev., 2012, 41, 6178-6194; (e) R. Farr, D. S. Choi and S. W. Lee, Acta Biomater., 2014, 10, 1741-1750; (f) M. A. Bruckman, G. Kaur, L. A. Lee, F. Xie, J. Sepulveda, R. Breitenkamp, X. Zhang, M. Joralemon, T. P. Russell, T. Emrick and Q. Wang, ChemBioChem, 2008, 9, 519-523.

8 (a) S. Honarbakhsh, R. H. Guenther, J. A. Willoughby, S. A. Lommel and B. Pourdeyhimi, Adv. Healthcare Mater., 2013, 2, 1001-1007; (b) K. L. Kozielski, Y. Rui and J. J. Green, Expert Opin. Drug Delivery, 2016, 13, 1475-1487; (c) M. Wu, J. Shi, D. Fan, Q. Zhou, F. Wang, Z. Niu and Y. Huang, Biomacromolecules, 2013, 14, 4032-4037; (d) N. M. Gulati, A. S. Pitek, A. E. Czapar, P. L. Stewart and N. F. Steinmetz, J. Mater. Chem. B, 2018, 6, 2204-2216; (e) P. Lam, R. D. Lin and N. F. Steinmetz, J. Mater. Chem. B, 2018, 6, 5888-5895; (f) A. S. Pitek, J. Park, Y. Wang, H. Gao, H. Hu, D. I. Simon and N. F. Steinmetz, Nanoscale, 2018, 10, 16547-16555.

9 (a) N. F. Steinmetz and D. J. Evans, Org. Biomol. Chem., 2007, 5, 2891-2902; (b) B. D. B. Tiu, D. L. Kernan, S. B. Tiu, A. M. Wen, Y. Zheng, J. K. Pokorski, R. C. Advincula and N. F. Steinmetz, Nanoscale, 2017, 9, 1580-1590.

10 (a) J. A. Luckanagul, L. A. Lee, S. J. You, X. M. Yang and Q. Wang, J. Biomed. Mater. Res., Part A, 2015, 103, 887-895; (b) A. Southan, T. Lang, M. Schweikert, G. E. M. Tovar, C. Wege and S. Eiben, RSC Adv., 2018, 8, 4686-4694; (c) 
L. Chen, X. Zhao, Y. Lin, Z. Su and Q. Wang, Polym. Chem., 2014, 5, 6754-6760; (d) X. Liu, J. Zhang, M. Fadeev, Z. Li, V. Wulf, H. Tian and I. Willner, Chem. Sci., 2019, 10, 10081016.

11 D. Ma, J. Zhang, C. Zhang, Y. Men, H. Sun, L. Li, L. Yi and Z. Xi, Org. Biomol. Chem., 2018, 16, 3353-3357.

12 (a) D. Ma, Y. Xie, J. Zhang, D. Ouyang, L. Yi and Z. Xi, Chem. Commun., 2014, 50, 15581; (b) J. Zhang, D. Ma, D. Du, Z. Xi and L. Yi, Org. Biomol. Chem., 2014, 12, 9528; (c) J. Zhang, Y. Men, S. Lv, L. Yi and J. Chen, Org. Biomol. Chem., 2015, 13, 11422; (d) D. Ma, X. Kang, Y. Gao, J. Zhu, L. Yi and Z. Xi, Tetrahedron, 2019, 75, 888-893.
13 (a) Y. Heider, N. E. Poitiers, P. Willmes, K. I. Leszczynska, V. Huch and D. Scheschkewitz, Chem. Sci., 2019, 10, 45234530; (b) L. P. Hammett, Chem. Rev., 1935, 17, 125-136; (c) L. P. Hammett, J. Am. Chem. Soc., 1937, 59, 96-103.

14 C. Hansch, A. Leo and R. W. Taft, Chem. Rev., 1991, 91, 165195.

15 (a) J. R. Fores, M. Criado-Gonzalez, M. Schmutz, C. Blanck, P. Schaaf, F. Boulmedais and L. Jierry, Chem. Sci., 2019, 10, 4761-4766; (b) H. G. Li, D. Buesen, R. Williams, J. Henig, S. Stapf, K. Mukherjee, E. Freier, W. Lubitz, M. Winkler, T. Happee and N. Plumeré, Chem. Sci., 2018, 9, 7596-7605. 